\title{
Simulation of transport processes and chemical reactions in building materials
}

\author{
Carina Jehn ${ }^{*}$, Frank Schmidt-Döhl \\ From 8th German Conference on Chemoinformatics: 26 CIC-Workshop \\ Goslar, Germany. 11-13 November 2012
}

Usually the prediction of the lifetime of building materials is based on costly and time-consuming laboratory experiments. Numerical simulation of transport processes and the resulting chemical reactions in building materials is a versatile tool to estimate durability and corrosion processes of structures. Several studies exist on the characterization of reactions in porous building materials and the resulting deterioration [1].

Chemical reactions between corrosive media and mineral building materials take place on the material surface as well as in the pore volume. Thus the program TransReac combines two main modules: chemical reaction involving thermodynamics and kinetics and the transport of species into pores [1,2].

Using thermodynamic parameters of involved species and experimental determinated transport characteristics of the examined building materials, reactions depending on time and position were simulated. Gibbs energy, density and other thermodynamic parameters, e.g. heat capacity can be found in $[3,4]$. This database is proved successful in building material research.

Different kind of chemical attack to mineral building material were simulated and verified by experimental data, e.g. corrosion caused by sulphate or ammonium solutions, acid and debonding of gypsum plaster [1,2]. The paper is concentrated on the dissolution of silica from aggregates in alkaline concrete pore solution at various temperatures, in regard to the simulation of the initial phase of alkali-silica-reaction of concrete.

Published: 22 March 2013

\footnotetext{
* Correspondence: c.jehn@tuhh.de

Institute of materials, physics and chemistry of buildings, Hamburg University of Technology, Hamburg, Germany
}

@ 2013 Jehn and Schmidt-Döhl; licensee BioMed Central Ltd. This is an Open Access article distributed under the terms of the Creative Commons Attribution License (http://creativecommons.org/licenses/by/2.0), which permits unrestricted use, distribution, and reproduction in any medium, provided the original work is properly cited.
References

. Franke L, Deckelmann G, Espinosa-Marzal G, Eds: Simulation of Time Dependent Degradation of Porous Materials Cuvillier Verlag: Göttingen; 2011.

2. Schmidt-Döhl F, Rostásy FS: A model for the calculation of combined chemical reactions and transport processes and its application to the corrosion of mineral building materials. I. Simulation model, II. Experimental Verification. Cem Concr Res 1999, 29:1039-1054

3. Harvie $\mathrm{CE}$, Möller $\mathrm{N}$, Weare $\mathrm{JH}$ : The prediction of mineral solubilities in natural waters: the $\mathrm{Na}-\mathrm{K}-\mathrm{Mg}-\mathrm{Ca}-\mathrm{SO}_{4}-\mathrm{Cl}-\mathrm{OH}-\mathrm{HCO}_{3}-\mathrm{CO}_{3}-\mathrm{CO}_{2}-\mathrm{H}_{2} \mathrm{O}$ system to high ionic strength at $25^{\circ} \mathrm{C}$. Geochimica et Cosmochimica Acta 1984, 48:723-751.

4. Reardon EJ: An ion interaction model for the determination of chemical equilibrium in cement/water systems. Cem Concr Res 1990, 20:175-192.

doi:10.1186/1758-2946-5-S1-P13

Cite this article as: Jehn and Schmidt-Döhl: Simulation of transport processes and chemical reactions in building materials. Journal of Cheminformatics 2013 5(Suppl 1):P13.

\section{Publish with ChemistryCentral and every} scientist can read your work free of charge

"Open access provides opportunities to our colleagues in other parts of the globe, by allowing anyone to view the content free of charge."

W. Jeffery Hurst, The Hershey Company.

- available free of charge to the entire scientific community

- peer reviewed and published immediately upon acceptance

- cited in PubMed and archived on PubMed Central

- yours - you keep the copyright

Submit your manuscript here:

http://www.chemistrycentral.com/manuscript/

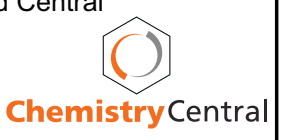

\section{(C) Chemistry Central}

